\title{
Financing Internationalisation: A Case Study of an African Retail Transnational Corporation
}

\begin{abstract}
Economic geographers are directing increasing attention to international expansion by leading retail TNCs. However, there has been minimal examination of the financing methods of these firms and, while the major retail TNCs have supply relationships in subSahara Africa, so far none have opened stores on the continent. Therefore in this paper we analyse expansion into sub-Sahara Africa by a second tier retail TNC (Shoprite) and explore its financing strategy. We find that the food retail sector in sub-Sahara Africa is experiencing strong growth with high financial returns. We identify a pecking-order to financing the firm - with a preference for internal funding through retained earnings preceding long-term debt, and limited issuance of equity as a last resort. Given the efficiencies of debt financing, this preference is interpreted as reluctance to dilute returns to shareholders and as a pragmatic approach to financing expansion in 'particularistic' business environments.
\end{abstract}

Key Words: Financing, Internationalisation, Retailing

JEL Classifications: L81, D92, F21

Revised November 2008

C. Charles Okeahalam $\left(1^{\text {st }}\right.$ author to be listed $)$

Benefit Advisory Research (BAR),

GROUP AGH,

Private bag X9, Postnet Suite 410

Benmore 2010, Johannesburg, South Africa

Email:co@groupagh.com

Tel. +27 118833733 Fax: + 27117845858

\section{Steve Wood}

School of Management, University of Surrey.

Guildford,

Surrey GU2 7XH

Email: sm.wood@ surrey.ac.uk

Tel: +44 (0)1483 686344 Fax: +44 (0)1483 686346 


\section{Financing Internationalisation: A Case Study of an African Retail Transnational Corporation}

\section{Introduction}

The rise of rapidly expanding retail transnational corporations (TNCs) has attracted interdisciplinary interest from across economic geography and a number of business and management sub-disciplines (Palmer et al., 2006; Wrigley and Lowe, 2007). This has contributed to an improved understanding of many aspects of the global retail expansion process including: management learning and knowledge transfer (Jonsson and Elg, 2006; Palmer, 2005); market adaptation and market impacts (Aoyama, 2007; Coe, 2006; Wrigley et al., 2005); global, regional and responsible sourcing (Coe and Hess, 2005; Hughes et al., 2007; 2008; Tokatli, 2006; 2008) and explaining the reasons for failure and market exit (Bianchi and Ostale, 2006; Christopherson, 2007). Amid this emerging research agenda (cf. Coe and Wrigley, 2007; 2009), in this paper we identify three partial gaps in our understanding:

First, published work has almost exclusively focused on the so-called 'first tier' retail TNCs originating from North America or Western Europe. Meanwhile research on the 'second tier' regional TNCs - for example, Dairy Farm in East Asia and Shoprite in sub-Sahara Africa - is limited.

Second, while there has been consideration of retail internationalisation in Africa by academics in development economics (e.g. Weatherspoon and Reardon, 2003), there has been minimal analysis of the impact of foreign direct investment across the continent in the 
areas of retail competitiveness, consumption practices, regulatory frameworks and supply network dynamics.

Third, we argue that despite some notable exceptions (e.g. Wrigley, 2000; Wrigley and Currah, 2003), there has been a lack of consideration of the strategies for financing international retail expansion.

In this context, our paper analyses the rapid expansion across sub-Sahara Africa of Shoprite, a 'second tier' South African food retail TNC. By drawing on interviews with key analysts and management, as well as a wide array of secondary data, it considers how and why Shoprite has funded its international expansion. We compare and contrast these funding mechanisms with those employed by first tier retail TNCs. In doing so, we seek to deepen our understanding of the financing and governance of retailers in different institutional contexts.

The paper is structured as follows: Section 2 briefly reviews the literature on retail internationalisation, firm governance and finance structures. Section 3 provides an overview of the prevailing retail environment in sub-Sahara Africa and highlights a number of key drivers of the rapid changes. Section 4 provides a brief history and operational review of the Shoprite group. Section 5 uses financial indicators to explain the reasons for the choice of funding method and Section 6 discusses our findings and suggests future areas of enquiry.

\section{Financing Retail Internationalisation}


Our paper seeks to contribute to the literature on finance structure, firm governance and institutional context in retail internationalisation. This is an area of considerable importance for economic geographers but has only been partially analysed in the literature. As Wrigley (1999a, 186) commented following his analysis of US food retailing deleveraging, 'shifts in the capital structures of firms recreate geographies in ways that are only now beginning to be understood'. In this section, we review how the finance strategies of retail TNCs and their governance are inter-linked and in doing so, note substantial gaps in our understanding.

\subsection{Firm governance and its implications}

Recent research in economic geography has paid considerable attention to the ownership structures and governance mechanisms of firms (Clark and Wójcik, 2007). Both have direct implications for firm funding and growth. The work of Wójcik (2003, 1434) draws a distinction between the so-called German model of governance - 'an insider, networked, bank-based, or closed system' and the Anglo-American model - that is 'open [and] marketbased'. Importantly for our paper, the rapid expansion of the first tier retail TNCs was facilitated by low cost capital, typically raised in the Anglo-American open system (Coe and Wrigley, 2007; 2009). This funding was obtained at a significantly less expensive rate than could be enjoyed by the indigenous retail competition which severely limited their ability to strategically respond to retail TNC market entry (Reardon et al., 2003). Typically debt and equity financing was easily raised as the cost of capital remained modest in the low inflation macro-economic environment of the 1990s. In part this was underpinned by favourable stock market conditions and successful domestic market retail performance which served to sustain market confidence. 
The Anglo-American model of governance is characterised by ownership by institutional portfolio investors in well established capital markets where takeover activities are common (Wójcik, 2003). Large institutional investors - notably pension funds - are instrumental in demanding corporate accountability, often insisting on disclosure and transparency beyond national regulatory standards (Clark and Hebb, 2005; Hebb and, Wójcik, 2005). Such is the influence of institutional shareholders on corporate behaviour that Clarke and Hebb (2005, 2028) argue that "we have entered a new phase in the relationship between large shareholders and their firms'. While other shareholders can also influence the direction of corporate strategy (Clark et al., 2008) they may have their influence lessened by ownership dispersion (Clark et al., 2006).

The open market for corporate control and influence is contrasted by the closed German model that is characterised by concentrated ownership that disciplines management rather than leaving it to the capital markets. Typically there is investment focused on the generation of long-term value' which 'seeks to satisfy multiple 'insider' stakeholders assuming that short-termism would otherwise undermine long-term competitiveness' (Bauer et al., 2008, 442). A wide array of studies suggest that this form of closed governance is declining across Europe as it is superseded by the open Anglo-American model (see Clark and Wójcik, 2005; Wójcik, 2002; 20003; 2006).

We argue that understanding these governance systems and institutional environments of retail TNCs is important as they have implications for capital structure which in turn directly affect corporate strategy. Indeed, the explicit linkage between the funding mechanism, 
ownership structure and corporate strategy is well known in the strategic management and finance literature. As O'Brien $(2003,428)$ notes:

'capital structure is not just a function of exogenous industry, regulatory and product market factors, but also of a firm's strategy and its basis for competition within an industry. This suggests that capital structure cannot be treated as either exogenous or irrelevant to strategy. Managers who fail to realize that an inappropriate capital structure can hamper the effectiveness of a firm's strategy, and thus hinder a firm's ability to compete, may suffer significant performance consequences'.

Given the explicit linkage here between finance and spatial outcomes, the capital structure of international retailers should be a key concern for economic geographers.

\subsection{International retailing and the governance implications of external funding}

A finance structure based on debt and equity raised in an open Anglo-American system of governance has important corporate control characteristics. Most obviously oversight is achieved through formalised systems of corporate governance that seek to overcome the separation of ownership and control (Shleifer and Vishny, 1997). In addition, we earlier acknowledged the role of institutional investors, and, to a lesser extent, shareholder activism in influencing standards of corporate behaviour and disclosure (Clark et al., 2008; Clark and Hebb, 2005; Hebb and, Wójcik, 2005). Given these array of pressures, Palmer and O'Kane (2007) argue that economic geographers should consider the discursive nature of corporate governance. In doing so, the direction of strategy is determined through processes of “argumentation" as retail TNCs must win acceptance and approval from key stakeholders for their strategies (Palmer and O'Kane, 2007). 
Palmer and Quinn's $(2003 ; 2005)$ qualitative research has been instrumental in deepening our understanding of how internationalising retailers negotiate the funding/governance nexus. In particular, they analyse how investment banks and analysts actively engage in strategy-building within retail TNCs. Palmer and Quinn $(2003,1394)$ suggest that the ability to attract funds for international retail expansion 'is largely based on the positive or negative market sentiment expressed by key analysts in the sector'. Similarly, Wrigley and Currah $(2003,237)$ emphasise the 'vitally important relationships between firms and the suppliers of finance'. This places a significant importance on retailers' ability to manage relationships with lenders which can ultimately become a key source of competitive advantage (Balakrishnan and Fox, 1993, 3).

While the leading first tier retail TNCs were able to successfully raise capital through debt and equity markets during the 1990s, the financial markets had certain preferences for the form such internationalisation would take and made these views clear. Palmer and Quinn's (2003; 2005) interviews with investment analysts underlined an initial negative view of internationalisation, particularly where merger and acquisition was utilised as a market entry method. This emphasised analysts' scepticism regarding the realisation of synergistic benefits from retail mergers (cf. Wood, 2002) as well as their concerns regarding pressure on short term performance. Instead, Palmer and Quinn (2003) note, there was a preference for expansion on an organic store-by-store basis with foreign markets entered early. Here much of the funding would be provided by working capital on the back of suppliers' credit with minimal recourse to equity capital or debt financing. Such a strategy often proved possible for leading international retailers - licences were relatively easy to obtain in underdeveloped markets, the costs of site acquisition and development low, and the existing 
competitor set often proved unsophisticated and lacked the necessary scale to provide strong competition (Coe and Hess, 2005).

On one hand, it is well known that direct entry into new markets via mergers and acquisitions may be easier to value by the capital markets because there are historical records of firm performance. In contrast, organic development lacks any such historical data, resulting in high information asymmetry that makes risk assessment difficult (Kochhar and Hott, 1998, 603). It should also be noted that capital markets are more likely to offer better credit terms if the nature of the asset that they are funding is less specific but transferable to alternative uses and/or to alternative owners. As a worst case scenario, 'high specificity implies that potential suppliers of funds may lose much of their investment if the firm enters bankruptcy' (Kochhar and Hitt, 1998, 608). This further supports incremental expansion by organic means which reduces up-front sunk costs. In practice, first tier TNCs have proved flexible in their entry methods; often pursuing acquisition or joint ventures before embarking on organic growth. This allows the retailer to gain scale and market position within a country, especially when facing a robust competitor-set that would make an initial lengthy period of organic expansion unworkable (Burt et al., 2006).

Given the governance role that financial institutions have in financing first tier internationalisation, there are considerable challenges for retailers in managing expectations and maintaining support from a wide range of financial actors including investment bankers, analysts, fund managers and brokers. Over the past 15 years many of the first tier retail TNCs have successfully managed such relationships given their strong brands and consistent performance. In part, this market confidence relied on trust and open disclosure from the 
firms. For example, in the case of UK food retailers, Hutchinson and Hunter $(1995,76)$ identify higher than average degrees of debt at a lower cost of debt capital due to "certain intangible assets which have reputation value' and which capital markets view as 'potentially underpinning and enhancing their product market positions'. However, in planning expansion there appears to be a disconnection between the expectations of financial institutions and the reality of international retailing with regard to the timescale of investment returns:

'Financial institutions have traditionally taken a short-term view of company performance where share prices have placed too much weight on short-term profits and dividends. However, it is widely acknowledged that retail expansion into new markets, particularly emerging markets, requires a long-term commitment' (Palmer and Quinn, 2003, 1398).

This places an emphasis on retailers managing the relationship carefully; keeping a grip on the internationalisation strategy but also maintaining robust communication between the firm and the finance providers. Clearly then, the investment community are viewed as active contributors to the formation of corporate retail international strategy: on the one hand they 'can inhibit or constrain international expansion yet may also act as a catalyst and facilitator of international expansion' (Palmer and Quinn, 2005, 1403).

\subsection{Stresses with financiers and institutional context: capital structure implications}

The open Anglo-American model of governance relies on strict standards of disclosure by firms that allows the capital markets to accurately value companies and their activities. Such clear communication is essential as 'globalization without rigorous capital market scrutiny based upon high standards of disclosure and transparency between markets can lead to the destruction of corporate value' (Clark et al., 2006, 317). 
Given the range of finance stakeholder relationships juggled by the first tier of international TNCs, along with their entry into challenging environments, it is unsurprising that there have been significant examples where stresses have occurred. These stresses have often caused difficulties, necessitated adaptation, and, at worst, hastened international market exit. For example, UK food retailer Sainsbury's found its room for manoeuvre restricted in the US when the capital markets lost patience with its home market performance (Wrigley, 2000). Indeed, home market performance remains important to internationalisation, as home revenues smooth overall returns particularly at the start of the expansion process (Alexander and Quinn, 2002). Meanwhile, Dutch food retailer, Royal Ahold, which had enjoyed considerable support from the capital markets during its 1990s period of expansion through cross-listing (Clark et al., 2006), was heavily penalised by its finance providers when its performance deteriorated (see also Palmer and Quinn, 2007). As summarised by Wrigley and Currah $(2003,225)$ :

'It had been forced to issue successive profits warnings and to announce a dramatic retreat from its previous corporate strategy of acquisition-driven growth to one of consolidation and organic, 'capital-efficient' growth. The equity market had effectively become closed to Ahold for funding purposes, and downgrading of its credit rating ensured that it had strictly limited access to the debt markets'.

Clearly the favour of the financial markets can evaporate if perceptions of current and future prospects of success appear ambiguous. This underlines the need for a capital and governance structure that is suited to the expansion strategy. Particularly important for our study of African retail internationalisation is the requirement for a resilient 'long-term, embedded and sustained investment' (Wrigley and Currah, 2003, 237) given that 
international expansion is well known to be 'inevitably accompanied by periods of retrenchment and strategic readjustment' (Wrigley and Currah, 2003, 234).

In part the challenge of satisfying external funding providers serves to underline the role of institutional context in influencing the financial structure of an internationalising retailer. As the finance literature reminds us:

'the strength and the nature of the effect of firm-specific as well as market related factors on the capital structure choice of a firm are dependent on the economic and legal traditions of the country in which it is located' (Antoniou, 2008, 87).

Whitley's (2001a, 2001b) work on differing business environments is useful here. He produces a typology of different types of business environment that has been developed to frame recent work on retail internationalisation (see Wrigley and Currah, 2003; Wrigley et al., 2005). This three-fold definition consists of: first, 'collaborative' environments where the state regulates finance flows rather than co-ordinates it, leaving finance to flow through competitive capital markets, such as in the United States. Second, 'collaborative' environments, where the state acts in a mediating and development role to channel investment, such as in much of mainland Europe and Japan. Finally, Whitley (2001a, 39) notes 'particularistic' environments that combine 'a weak and/or predatory state ... with weak collective intermediaries and norms governing economic transactions' (cited by Wrigley and Currah, 2003, 223).

Importantly investment in 'particularistic' business environments may have implications for a firm's capital structure, not least within under-developed financial markets: 
'Capital markets are unlikely to be significant sources of investment funds in such societies and the largely personal nature of authority relationships will restrict the development of strong labour unions. Social relationships in these cultures tend to be highly personal and particularistic' (Whitley, 2001b, 87).

Hence, not all external financing mechanisms will necessarily be available to the firm as information asymmetry may be considerable, rendering emerging stock markets ill-suited for raising funds. In turn, this may lead to "non-optimal financing decisions in terms of the theoretical assumptions of capital structure theories' (Eldomiaty, 2007, 27).

Particularistic environments such as Africa therefore expose retailers (and ultimately finance providers) to significant investment risk but also considerable opportunity given its untapped nature by first tier retailer capital. Indeed, more generally, it is known that investors are realising the attractive growth rates and higher returns that emerging markets may offer (Hebb and Wójcik, 2005). Managing investment and strategic risk is key here: for example in terms of entry method such as via partnerships and joint ventures (Wrigley et al., 2005), but also in selecting a financing structure that allows maximum returns yet is also resilient enough to endure the strains and stresses of new markets.

\subsection{Capital structure theory - insights from the financial literature}

Given the importance of the finance structure decision, what are the options open to retailers and how are they treated in the finance literature? Financing incorporates sourcing, allocation, management, control and profiling of monetary assets and risk. The challenge for financial managers is to determine the ideal mix of funding sources for the particular company and its circumstances (McCaffrey et al., 1997). According to Chowdhry and 
Coval (1998), sources of external financing are normally a combination of debt and equity each with widely varying firm-level implications.

In a well-known review article, Myers (2001) mapped out three main capital structure theories that serve to inform the potential strategies of firms. First, 'trade-off' theory states that firms seek debt levels that balance the tax advantages of additional debt against the costs of possible financial distress. Tax advantages arise because the interest payments that companies make when they utilise debt capital can be set against corporate tax liabilities (McCaffrey et al, 1997). This is common across retailing. As Ian Coull, a former Director of UK food retailer, Sainsbury's, suggested, 'It is almost corporate ineptitude not to have some form of debt to develop your business...it's crazy not to do it, you are cheating your shareholders' (Wrigley, 1997, 55). However, at some point the tax advantage is eroded by costs associated with financial distress (Myers, 1977; Aivazian et al. 2005). Unsurprisingly given the turbulent nature of retail revenue streams, in a survey of capital structures in UK retailing, Hutchinson and Hunter, $(1995,64)$ noted how operators retain 'some form of 'financial slack', to guard against the full affects of adverse trading conditions.

Second, Myers $(2001,81)$ explains the free cash flow theory that draws on the agencyrelated arguments of Jensen and Meckling (1976) to explain why 'dangerously high debt levels will increase value, despite the threat of financial distress, when a firm's operating cash flow significantly exceeds its profitable investment opportunities'. The addition of significant debt to the capital structure of the business is seen as unifying the interests of management and shareholders. Without such coercion, managers are seen as having a propensity to expand the scale of the firm, even if that means undertaking poor projects and 
reducing shareholder welfare. The issuance of debt signals managerial commitment to improved performance. It also pre-commits the firm to pay cash interest and the principal, forcing managers to service such commitments with funds that may otherwise have been allocated to poor investment projects (Jandik and Makhija, 2005).

This strategy has been successfully employed via highly leveraged transactions in the US food retail market (Wrigley, 1999a; 1999b), but disastrously in the US department store sector due to excessive debt burdens (Wood, 2008). Given that this capital structure is applicable only to mature businesses that are prone to overinvest rather than rapidly growing ones, it is unlikely to be adopted by internationalising retailers that require a consistent and reliable investment flow in order to expand.

Finally, Myers (2001) discusses the so-called pecking order theory that states that firms will have a preference for internal funds, then low-risk debt, and then, if this is insufficient for their needs, equity as a last resort. The capital structure of a firm is not the result of a preordained strategy, but instead 'simply arises from a company's past incursions into the capital markets when retained earnings, the most preferred source of financing, were insufficient to cover investment needs' (McCaffrey et al, 1997, 129).

The pecking order thesis finds support from a range of studies (Dyson and Rasaratnam, 2006). Myers and Majluf (1984) suggest that a firm with ample financial slack - for example, large holdings of cash, liquid marketable securities, or the ability to issue low default/risk-free debt - will attempt to take-up all potentially profitable opportunities. Conversely, a reduction in such slack would lead to some of the opportunities being passed 
up. Similarly, Fazzari et al. (1988) find that internal finance in the form of retained earnings generates the majority of returns for firms, though other sources of funding such as company loans, venture capital resources and initial public offerings are often also required (Chowdhry and Coval, 1998). Finally, Fazzari et al. (1988) suggest that for signalling reasons, large firms may reduce investment when cash flow falls, rather than seek more costly external finance. Seen in this light, the recent literature on asymmetric information and capital market imperfections (Bellalah and Belhaj, 2003) demonstrates that a firm's opportunity cost of internal funds can be substantially lower than its cost of external finance.

The stage of growth of a firm is also known to be related to the finance structure selected. Gabrielson et al. (2004) attempt to relate different capital structure preferences with different phases of the expansionary process. The first phase is concerned with the start-up. Choices here tend to be between the founder's own investments or external financing, with banks being the key source in the latter. Importantly for our study, in an African context, it is wellknown that there is a high-dependence on banks in start-ups (Okeahalam and Adams, 2000). The second phase is internationalisation and commercialisation; rapidly expanding firms tend to rely on the formal market and raise capital from investors and financial institutions, and in certain instances, venture capital funds. Obstacles to growth and expansion are thus greater in the third, 'global' phase. This usually requires significant expansion capital which is sometimes raised internationally.

To summarise, this section has underlined the extent to which economic geography has analysed different models of firm governance that have implications for the manner in which the firm raises capital and are controlled. Within first tier retail TNC expansion, it is clear 
that there has been a reliance on the capital markets to fund international growth in an Anglo-American open system. In doing so, recent research has examined the degree to which retailers have to maintain a clear dialogue and transparent disclosure with their stakeholders as well as being reactive to their demands. The penalty of losing the confidence of the capital markets is severe and potentially results in divestiture and retrenchment.

What the literature has less evidence of though is the degree to which second tier retail TNCs fund expansion and the implications of entering 'particularistic' markets where risk profiles attached to capital are likely to be higher. Therefore, by analysing the strategies employed by Shoprite, we seek to answer a key question posed by Wrigley et al. (2005, 444): 'In what ways have retail TNCs managed significant investment since the mid-1990s in unpredictable, weakly institutionalized, 'particularistic' business environments...?' The remainder of this paper seeks to examine this issue. In Sections 4 and 5 we consider the financing of Shoprite's international expansion through the lens of these insights. However, first, we must place the retailer within the context of the rapidly changing retail environment in sub-Sahara Africa.

\section{The Rapidly Changing Face of Grocery Retailing in Africa - A Brief Typology}

Over the last two decades many of the economies of sub-Sahara Africa have been through stages of structural adjustment and other types of reform. On the whole, this has improved their macroeconomic performance and outlook. Growth in the provision of basic infrastructure and the take up of information technology has been rapid. Concurrently the 
food retail sector in the region has begun to dramatically develop its store and supply chain networks.

For the most part, food retailing in sub-Sahara Africa is characterised by unregulated openair 'wet' markets with the development of supermarkets being a recent phenomenon (Reardon et al., 2003; Weatherspoon and Reardon, 2005). Wet markets sell a wide variety of perishable and non-perishable goods often organised in a haphazard fashion. Ownership is highly disaggregated and there are low levels of industrial concentration. Most grocery retail businesses are still largely family-owned and in the rural areas in particular, women are frequently the owners and managers.

With rising incomes and living standards, tastes are changing and evidence from retail consumption patterns indicates a trend away from open-air markets, especially in urban areas of southern Africa. Two related factors explain this. The first is infrastructure development (roads, electricity) which enables efficient supply chains to function. Notably this has happened to a greater extent in Kenya compared to other countries in east Africa and similarly we find that supermarket development is far more advanced here (Reardon and Neven, 2004). The other factor is industry structure. Efficient supply networks engender scale and market power, which reduces the competitiveness of small scale retail outlets.

The opportunities offered by the 'modern' retail sector have not gone unnoticed although some countries in Africa have been hesitant to embark on the policy reforms necessary to exploit FDI. As Moss et al. $(2005,362)$ note, this hesitation has its routes in 'deep-seated sentiments against foreign capital' with its inherent linkages to the colonialism tendencies of 
the past. While this explains the low profile that Africa has in a number of contemporary analyses of retail internationalisation (e.g. Dawson, 2007; Wrigley and Lowe, 2007), recent developments have seen the spread of supermarkets into sub-Sahara Africa driven by substantial FDI from a more local source: South Africa. In part this has also been facilitated by the trade liberalisation policies of some African countries. For example, Shoprite's entry into Zambia was facilitated by the purchase of Government-owned supermarket stores in 1996 (Miller, 2005, 127).

Weatherspoon and Reardon (2003, 335) note that rapid developments occurred initially in more economically developed countries such as South Africa, Kenya, and Nigeria. There then followed a 'second round' of retail TNC development due to substantial FDI (principally from South Africa, but also recently Kenya) that has penetrated a number of southern African developing countries (including: Zimbabwe, Zambia, Namibia, Botswana, Swaziland, and more recently Madagascar, Mauritius, Angola, and Mozambique). Penetration of eastern African countries (such as Uganda and Tanzania) has only recently begun. This has led to a highly differentiated geography of supermarket penetration within Africa: while South Africa has c.55\% of its sales channelled through supermarkets; this is as low as 5\% in Nigeria (Reardon et al., 2003).

As detailed in the wider retail internationalisation literature, there is a general tendency for retail TNCs and their subsequent supermarket formats 'to spread progressively from their original niches in major cities serving predominantly the rich and middle class, to smaller cities and rural towns, and to serving the lower middle class and working poor' (Coe and Wrigley, 2007, 350). Consistent with this model of development, expansion flowed from 
southern to eastern Africa and from the more obvious sites within large, affluent markets to smaller towns and poorer areas. This has resulted in "supermarkets for the poor" - with market extension away from being mere luxury top-end niche providers to becoming mass market merchandisers (Weatherspoon and Reardon, 2003). Format extension is also occurring with supermarkets being complemented by hypermarkets and convenience stores along major transport routes and in densely populated areas.

Given the 'particularistic' investment environments that characterise many of the African countries experiencing retail development, the retail TNCs have had to face considerable risks. Some of these markets have proved politically and economically unstable, notably Zimbabwe. Specifically, deficient infrastructure and bureaucratic trade agreements have posed severe challenges to operational performance. For example, the Zimbabwean Parliament recently passed a nationalisation bill that requires all foreign companies to sell or in effect cede $51 \%$ of their share ownership to locals. Despite the economic meltdown in Zimbabwe, Shoprite indicated that it would not disinvest.

It is important to note that the impact of transnational retail FDI on host economies is not uniform or uncontested (Humphrey, 2007; Palmer and O'Kane, 2007). Entry into other African markets by South African retailers has required careful political and cultural management. Miller (2006), for example, uses a case study of Shoprite branches in Mozambique and Zambia to illustrate the nature of resistance to entry by South African firms into a number of African countries. However, the political and operational risks in some of the African markets are offset by generally higher store margins than enjoyed in the domestic market. Therefore Shoprite's expansion has mirrored the geography of the 
expanded democratic space and improving investment climate in several African countries (Miller, 2005). More recently, the active interest expressed by other retailers in sub-Sahara African markets reflects growing confidence in the region and the potential for the development of store and supply chain networks.

\section{Shoprite - History and Operations}

The South African retail industry is composed of two dramatically different markets: formal and informal. The formal sector is highly consolidated with two companies, Shoprite/Checkers and Pick n Pay, accounting for approximately $80 \%$ of sales, with Spar and Woolworths accounting for a further $10 \%$ and 5\% respectively (Reardon et al., 2003, 1142). The informal sector is composed of hawkers, small stands and finally spazas (shops found in poor areas of cities and rural towns) - a structure very similar to the retail sector in other parts of sub-Sahara Africa.

In this section of the paper, the history and development of Shoprite is reviewed, concentrating on its operational and financial performance between 1995 and 2006 - the era of its fastest international expansion. ${ }^{1}$

** Table 1 about here **

The Shoprite Group of Companies started in 1979 from small beginnings in the Western Cape region of South Africa when a group of entrepreneurs purchased eight supermarkets from the Rogut family for one million rand. Through an aggressive acquisitions and innovative expansion strategy, principally based on reinvesting retained earnings and 
drawing on a deeply entrenched entrepreneurial culture in the firm, Shoprite has expanded to over 1,000 owned and franchised business units. These operate in 17 countries across Africa, the Indian Ocean islands and southern Asia. Indeed, the most recent data on African food retailing suggest that for 2005 Shoprite registered the highest sales among all retailers trading in the Africa and Middle East region (Heins, 2005).

Shoprite listed on the Johannesburg Stock Exchange in 1986 and now has secondary listings on both the Namibian and Zambian Stock Exchanges. Cross listing is well known as a strategy to raise low cost capital but also to potentially exploit 'the interest of minority shareholders who share neither the expectations of domestic investors nor the assumption of a settled landscape of firm-specific growth opportunities in the global marketplace' (Clark et al., 2006, 307). As at $21^{\text {st }}$ September 2007, Shoprite had a market value of 21.8 billion rands and the majority of the approximately 539 million issued shares were held by asset managers, pension funds and management. The ownership structure could be classified into four main groups: institutional asset managers and pension funds held $70.8 \%$ of shares issued; other financial institutions such as banks held 8.1\%; and university pension funds and endowments held approximately $4.7 \%$. Finally, management and a number of individuals and trusts held shares equating to approximately $16.5 \%$ of the shares issued - a relatively high ownership level which we argue significantly influences a preference for internal financing within the firm.

\subsection{Shoprite and its strategic growth approaches}

Shoprite operates a two component expansion strategy: first, to continue to build its domestic market share; and secondly, to simultaneously develop its international presence. 
It is important to recall that home market performance remains essential in the internationalisation process. This is seen both in terms of providing a source of funds for reinvestment through retained earnings but also as an important signalling function essential to retaining the confidence of the financial markets (Alexander and Quinn, 2002; Coe and Hess, 2005; Palmer, 2005).

Key to this expansion process is Shoprite's development of new retail formats, market entry and execution procedures. The retailer trades 'a variety of formats, aimed at different income classes' (Humphrey, 2007, 440) which include: hypermarkets, supermarkets, discounters, convenience, and cash \& carry stores. Each of these formats is represented by one or more of the business units in Table 2. According to Colla (2003), the synergies available with multiple format groups favour international expansion as this reduces the risk of entry and can enhance operational efficiency, boosting financial returns.

** Table 2 about here $* *$

This flexible approach to achieving growth is central to the successful realisation of retail internationalisation not simply between different countries, but also between different catchments and markets within countries: 'individual retail TNCs will do things differently in different markets - for example, in terms of mode of entry, store expansion programmes or supply chain management - even if the markets fall into the same metacategory of 'particularistic" (Wrigley et al., 2005, 447). For example, while a supermarket retailer by strategic orientation, Shoprite's Usave format, a no-frills small-format chain, sells a limited range of goods at prices well below those of other major retailers because of its low 
overhead cost structure. This allows Shoprite to reach a wider spread of customers in new markets with minimum risk.

Shoprite has also used franchising to ameliorate development risk, especially in 'particularistic' environments associated with greater investment hazards: for example, when attempting to exploit emerging middle class markets in traditionally poorer areas. Notably, prior to the end of Apartheid, townships had been prohibited markets for supermarket retailers (Weatherspoon and Reardon, 2003; cf. Tuston and Strydom, 2006). With a franchising strategy, instead of Shoprite incurring the considerable sunk costs of site acquisition, store construction and fit-out (cf. Clark and Wrigley, 1997a; 1997b), 'the franchisee bares the majority of the financial burden' (Doherty, 2007, 194). As at December 2007, Shoprite had 260 franchised stores versus 960 owned units (Shoprite, 2008). By adopting a variety of strategies, Shoprite has become the first retail firm to commit to meaningful entry into a number of African economies (see Figure 1).

** Figure 1 about here **

\subsection{Supply networks and Shoprite's adaptation}

The internationalisation literature has underlined the challenges for retail TNCs entering under-developed markets in terms of building dependable and high quality supply networks (Coe and Hess, 2005). The typical model for constructing supply chains has been for the retailer to source processed foods first; semi-processed second; and lastly fresh (Reardon et al., 2007). While retailers are keen to impose their own centralisation logic to sourcing 
(Reardon et al., 2003), this often proves challenging in terms of ensuring supplier size, quality assurance and traceability (Humphrey, 2007).

Shoprite have responded to these supply chain challenges by making two strategic acquisitions (Reardon et al., 2003; Weatherspoon and Reardon, 2003). First, in 1995, Shoprite acquired Sentra, a central buying organisation that caters to 550 retail members. Second, Shoprite purchased the specialised wholesaler, Freshmark. This organisation operates an array of distribution centres and has a system of preferred suppliers and growers. As Weatherspoon and Reardon (2003, 338-9) note:

'Having that procurement capacity was the foundation stone for the supermarket and convenience store franchising operation it launched in the second half of the 1990s that allowed expansion of its brands/franchisees into the former homelands and into poorer, rural towns'.

\subsection{Shoprite sales growth}

Figure 2 presents nominal financial statement data for gross revenue (sales turnover) and net profit. It shows that Shoprite's turnover grew exponentially during the 1995-2006 period, and highlights the difference between sales and profits. Retained earnings and internal cash flow has largely funded the international expansion. Underlying cash generation in South Africa has been facilitated by a progressively stable domestic macro economic environment and on-going wealth redistribution initiatives. This has given rise to an emerging middleclass which allows the opening up of trading opportunities in previously disadvantaged areas.

** Figure 2 about here ** 
Although Shoprite still generates approximately $80 \%$ of its turnover in the South African market, improved economic and political stability elsewhere in sub-Sahara Africa has had a positive effect on growth. Our interviews confirm that the aim of senior management is to increase the operating income from other sub-Sahara Africa countries to more than $50 \%$ of group revenue.

Over the 1995 -2006 period, Shoprite has registered positive net profit growth. However of late, as a proportion of sales, this has declined somewhat which is indicative of a sharp increase in operational expenditure as its international expansion process has accelerated. In particular, employee costs have risen sharply with investment in human resources both at the managerial and store level.

\section{Financial Analysis - An Explanation of the Preference for Investment with Internal Funds}

This section assesses the way in which Shoprite has financed its domestic and international expansion and seeks to explain its use of internal funding through retained earnings. An understanding of this issue is important because, as Okeahalam (2005) indicates, the capital markets of sub-Sahara Africa are far from perfect with the selection of an optimal financial structure consequently difficult to deduce. Part of this problem stems from the high degree of information asymmetry that pervades emerging stock markets. As Eldomiaty (2007) notes more generally, the theory concerning capital market structure may not be applicable to firms in developing economies due to the lack of sophistication of the investment environment. 
Two key strategic decisions clearly influenced financial performance at Shoprite during its first period of its expansion, focused on the domestic market. First, between 1996 and 1997, Shoprite acquired the loss-making OK Bazaars Group and entered the Quick Service Restaurant (QSR) market. Second, in the following year, it used cash and retained earnings to acquire Sentra (as confirmed in discussions with analysts) and also invested in its first store outside of South Africa. The initial success of the use of cash and retained earnings cemented its use in subsequent domestic and international expansion.

The main focus of the second period (1998-2000) involved the restructuring of OK Bazaars Group, which proved to be a complicated and expensive process. However, at the same time, Shoprite entered a joint venture agreement with a North African company, and continued to test the sub-Sahara Africa market by opening two more stores. The rate of entry into African retail markets then increased significantly in the third period (from 2000 onwards). The relationship between the decline in profit levels and Shoprite's domestic and international expansion process can be seen in some annual company reports. For example, the 2006 company report attributes the increment in staff costs to the opening of an extra 66 stores. It also indicates that a considerable proportion of the increased operational expansion was primarily financed by resources generated from business operations.

** Table 3 about here **

Yet Shoprite still has high liquidity levels and, as Table 3 above indicates, despite the financing strategy adopted, retained earnings and dividend payments increased. Indeed, the significant growth in retained earnings supports the view that Shoprite used internal resources to fund its expansion. The Shoprite CEO was quoted in the 2001 company report 
suggesting that 'the Group is flush with cash resources exceeding R900 million and it is well placed for any future expansion opportunities'. The retained earnings pool grew strongly, particularly from 2001, allowing borrowing to taper-off and the retailer to steadily increase its amortization rate. By end of 2005, Shoprite had invested as much as R780 million (US $\$ 112$ million) in operations outside South Africa. To put this in context, although such expansion activity and investment is sizeable from an African perspective, in global terms this is far less significant. Thus the relatively small scale of funding required may also explain why internal sources continue to be favoured.

\section{** Figure 3 about here **}

The level of interest bearing debt finance charges in the annual financials confirms that Shoprite also uses some long-term leverage. Sharp increases in borrowing (although still comparatively low) were registered in some years. Company reports and interviews did not offer any explicit link between the marginal increase in debt, dips in profitability and the group's expansion activities. However, as Figure 3 and Table 3 indicate, when the firm increased its use of internal resources, it also reduced debt levels, leading to an overall steady decline in long-term borrowing. The progressive reduction in the group's long term indebtedness indicates a combination of a general reduction in borrowing and increased finance charges. It also reflects entry into a number of markets where it remains unlikely to receive debt funding from South African banks.

** Figure 4 about here **

The number of shares in issue also provides some insights into the impact of increased expansion and financial performance. As shown in Figure 4 and a number of annual reports 
(1998-2001), the first increase in shares in issue coincided with Shoprite's first venture outside South Africa and the entry by Sentra into franchising. The second increase corresponds with expansion activity in the domestic market through (as noted earlier) acquisition of the ailing OK Bazaars Group and entry into the Quick Service Restaurant (QSR) market. A share consolidation between 2001 and 2002 returned share capital to circa 1996 levels and reaffirms the view that outside equity financing has played a limited role in Shoprite's balance sheet and international expansion.

Ratio analysis allows us to identify changes over time and can also be used to assess how the firm funds its expansion. To add clarity to this, the performance and operations of Shoprite are benchmarked against immediate competitors and peers such as Pick n Pay and Massmart. This comparison is critical because financial ratios convey little in isolation, but must be compared against yardsticks, adjusted for exchange rate conversions (where necessary) and interpreted together with other non-financial indicators. ${ }^{2}$

Putting the financing of Shoprite in context, Figure 5 compares Shoprite's financial ratios with those of its two main domestic competitors. Firstly, Shoprite's average current ratio was 0.98 compared to Pick n Pay (0.87) and Massmart (1.03). The implication for Shoprite is that the group's capacity to fund its short-term financial commitments improved steadily over time. Massmart has steadily managed its current ratio to a point of almost zero fluctuation, while Pick n Pay exhibits a negative trend in current ratio over time. The acid test ratio of the three retailers produces similar trends to the current ratio. ${ }^{3}$

\footnotetext{
** Figure 5 about here **
} 
The traditional view is that higher levels of gearing expose companies to greater financial risk due to the increased volatility of profits (Kieso and Weygandt, 1986). For the most part, Shoprite's gearing generally remained below the $40 \%$ mark apart from 1996 when it rose to over 50\%. Indeed, the three retailers have had comparable levels of gearing, with the average gearing at $20.3 \%$ for Shoprite, $26.4 \%$ for Massmart and $27.5 \%$ for Pick n Pay. However, over the review period, Shoprite exhibited the sharpest reduction in gearing. Furthermore, the financial performance of Shoprite's two competitors should be seen in context as neither embarked on international expansion.

\footnotetext{
** Figure 6 about here **
}

In general what do the trend and ratio analyses tell us? Firstly, they identify Shoprite's reliance on resources generated from internal funds to finance domestic and international expansion. In particular, the number of shares in issue indicates that in comparison to retained earnings and debt, outside equity played a limited role in financing the expansion activities. The firm issued shares twice during the period under review. Although both share issues coincided with extensive international and domestic expansion, shares in issue promptly reduced to circa 1996 levels - implying a receding role of outside equity financing in Shoprite's expansion activities.

As a general rule, debt financing has obvious cash flow implications in that it results in a liability that must be serviced. Equity financing is therefore less risky in the sense of cash flow commitments, but it results in a dilution of ownership and earnings. Furthermore, the tax deductibility on interest payments improves the competitiveness of debt relative to outside equity finance. Therefore the cost of equity is typically higher than the cost of debt 
and so equity financing may result in an increased hurdle rate which may offset any reduction in cash flow risk. Clearly, despite the relatively low credit risk of Shoprite, the overall strategy appears to have been to use debt sparingly. Indeed, the strength of Shoprite's credit status is demonstrated by sufficient interest cover in each year and the positive interest cover trend, as well as the low level of gearing. This confirms that internal funds generated in the domestic market have been ploughed into international markets.

Our analysis confirms that Shoprite relies on resources generated from operations and, to a more limited extent, retained earnings and borrowings. On the whole, Shoprite's financing strategy appears to support the pecking-order principle (Donaldson, 1961; see also Myers, 1984; 2001). However, given the tax advantages of debt and the potential for increased value of a leveraged firm, the use of internal funds by Shoprite requires further explanation. We argue that there are three main factors underpinning this strategy:

i) The underdeveloped nature of financial markets in 'particularistic' markets. With the exception of Kenya and Nigeria, the long bond markets in most sub-Sahara African host economies into which Shoprite is expanding are illiquid. This limits the effective competitive pricing and subscription of corporate bonds and the raising of funds in those markets. Therefore, the relative cost of financing in these host economy markets is high. Furthermore, in sub-Sahara Africa, for the most part, debt financing equals bank financing, which is more expensive than debt issuance. In essence South African firms have had to pay an African 'penalty' for funds to be deployed in investment in other parts of the continent. 


\section{ii) The likely negative reaction of the financial markets to expansion, which would be}

deemed high risk if exploiting external financing. Internationalisation strategies regarded as high risk tend to result in a deterioration of the financial profile of the retailer, and thus share price decline in the short-term (Palmer, 2005). Our earlier discussions expanded on the importance of maintaining relations with finance providers and the costs for retail strategy when they stall (cf. Wrigley and Currah, 2003). Furthermore, we noted the frequent mismatch between the timescales of expected returns from international expansion between the financial markets and the reality of international retailing (Palmer and Quinn, 2003). Therefore Shoprite's pecking order financing strategy appears pragmatic for long-term investment in environments perceived as high risk.

\section{iii) The entrepreneurial culture of management and the rate of growth of internal} funds relative to investment size. The high share of ownership of equity by the management of Shoprite has led to a convergence of interests between management and shareholders, and a lessening of the so-called agency problem in the funding and operation of the retailer (cf. Jensen and Meckling, 1976). As a result, there is a desire to take and manage risks and accrue to shareholders all of the possible returns of international expansion into sub-Sahara Africa. With adequate internal funds available for the majority of the investment requirements, and with sufficient returns from reinvestment, it was logical to continue to fund internally. Despite the relatively dispersed level of ownership, we argue that Shoprite's model of organisation has similarities to the German/closed style of governance (cf. Wójcik, 2002; 2003; 2006) focusing on longer term investment and retained earnings rather than short term profits. Indeed, management have consistently argued against high leverage on the grounds that some product lines and cash flows are vulnerable, 
and that the rapid international expansion into sub-Sahara Africa and foreign exchange volatility might dilute earnings. Thus given the financial accelerator principle, they suggest Shoprite would face an external finance premium. ${ }^{4}$

\section{Discussion and Implications for Future Research}

This study has contributed to the rapidly expanding literature on retail internationalisation in three ways: first, by analysing the expansion of a second tier regional TNC; second, by focusing on expansion in Africa - a region that has received minimal attention to date; and third by exploring the changing capital structure of an internationalising firm. At a basic level, our findings suggest that Shoprite has followed a pecking-order approach to financing its expansion. However, we argue that there are some considerable lessons for economic geography in terms of understanding firm funding in retail internationalisation.

In short, we find that different capital and governance structures in international retailing are appropriate for different investment environments and risk profiles. The majority of first tier retail TNCs have benefitted from open Anglo-American governance investment environments and have successfully raised capital to expand from the capital markets (Coe and Wrigley, 2009). However, if we accept that the challenge of good firm governance is to balance short-term opportunism and longer-term objectives (Clark, 2008), then it is clear that displaying the characteristics of a relatively closed system of governance, with a reliance principally on retained earnings, is appropriate for 'particularistic' environments in which Shoprite is located. Whilst Shoprite's domestic market is the most sophisticated in Africa, and parts of it mirror markets in Western Europe and North America, it is committed to an internationalisation strategy with a primary focus on the less developed markets of sub- 
Sahara Africa. The level of capital required to service that internationalisation strategy is relatively low, despite high returns. However on a longitudinal basis and given the 'particularistic' environment of expansion, the risk-premium attached to that investment is high. As a result the cost of capital is high - which implies a high hurdle rate on expected rates of equity return. While a reliance on retained earnings places emphasis on continued strong performance on the large, domestic South Africa market (cf. Alexander and Quinn, 2002), systematically raising extensive amounts of finance on the capital markets would have been challenging (and likely expensive). This was especially the case in Shoprite's initial periods of development where the risk profile attached to such investment would have been considerable. Similarly, going forwards, entry into other African countries is likely to be viewed with scepticism by conventional finance providers and may prove costly.

Shoprite's reliance on reinvesting profits is more pertinent in the current context of tightened global credit availability as it is less exposed and dependent on equity markets and external funding for growth. This serves to underline the reduced vulnerability associated with employing a prudent pecking order of funding expansion and contrasts with other international retailers who, in the past, have found their growth potential severely affected by a marked change in the attitude of credit markets to them (cf. Clark et al., 2006; Palmer and Quinn, 2007).

As noted earlier, there is often a disconnection between the timescales that capital markets and finance providers target for investment returns compared with the realities of international retailing (Palmer and Quinn, 2003). This leads Wrigley and Currah (2003, 237) to note that 'the critical issue then is what type of investment lends itself best to long- 
term sustainability'. As the era of low cost capital that has traditionally served international retail TNC growth well comes to an end, Shoprite looks likely to sustain its growth almost unabated. This is important as it is likely to offer the retailer greater time than it may have otherwise expected to shore-up its market position and secure its first-mover advantage across sub-Sahara Africa. As the work of Reardon et al. (2007) notes, prior to the shocks in the financial market, retail TNC growth was set to aggressively spread into the continent with the fourth wave of supermarket diffusion. More generally, before the credit crisis, it was noted that 'investors are turning their attention to the world's emerging markets, in which rapidly expanding growth rates generate higher returns on investment than home markets can provide' (Hebb and Wójcik, 2005, 1955-6). Hence it is likely that when the credit crisis abates, first tier TNCs will turn their attention to this continent of largely untapped potential. Establishing strong operations in the meantime will be essential.

Shoprite's internationalisation strategy clearly has implications for the way it finances its operations. However, over time this is likely to change, as it accrues the benefits of being the first retail firm to establish a network of stores throughout sub-Sahara Africa. The location of store sites and whether it changes its current preference to lease rather than purchase space will be key determinants of the degree of financial success. Renting space will minimise investment risk but also its ex-ante returns. The converse holds if it reverts to purchasing sites, since it would be buying when the level of capital investment required is still low. Over time, as asset prices in sub-Sahara Africa rise, which they likely will given that they are coming off a very low base, then it will have built a store of capital. 
Thus a first-mover retail TNC such as Shoprite should benefit from early-bird low entry cost, incumbency and rising capital barriers to entry and, in turn, this is likely to impact its financing strategy. Under such circumstances it is likely that a debt preference may emerge. This is because with rising endogenous fixed capital stock (collateral), the relative (to equity) price of leverage will decline.

Finally, we assess the implications of this study for further research within economic geography. Acceptance of the proposition that financing strategies will vary for different retailers in different internationalisation settings leads to a number of areas of future enquiry. Key amongst these in the current context is investigating how the financing of retail internationalisation will be affected by the credit crisis? Will those retailers that have largely relied on retained earnings and are consequently more insulated from the tightening of the capital markets be able to press home any strategic advantage? Similarly, we question the extent to which there are differences in the methods of financing employed by retail firms for domestic and international expansion. Providing answers to some of these and other related questions will help to deepen our understanding of the emerging economic geography of our rapidly globalising retail landscape. 


\section{NOTES}

1 Although Shoprite is expanding rapidly, its financial reports are not disaggregated into domestic or international segments and therefore provide no information on variations in the method of funding - of domestic or international investment. To consider this issue in some detail, this, and the subsequent section, uses publicly available information, discussions with retail analysts and an interview with senior management. The sensitive nature of the latter means that we are unable to provide direct quotations.

${ }^{2}$ Given the vast difference in scale of the SSA and major international retailers, the use of absolute figures for comparative purposes, is not very meaningful. Also, domestic exchange rates for the firms varied widely over the review period - particularly the significant volatility and devaluation of the South African rand during 2000-2001, which makes translation difficult. Meanwhile the scale magnitude reduces the usefulness of mean values. Furthermore, fitting Wal-Mart's or Tesco's earnings with one of the smaller retailers such as Shoprite, (even after conversion) into a visible graphical scale is almost impossible. The approach adopted here is to compare like-with-like, which means working with ratios. Three key ratios were selected: operating margins, which are an indication of efficiency, the expense burden carried by the retailers and an indicator of activity, including growth; the current ratio to show the retailers leveraging their power over suppliers as they expand and, lastly, debt to equity to show the proportion of the business funded by debt vis-à-vis owner's equity.

${ }^{3}$ Gearing refers to the percentage of a company's capital employed that is financed by debt and long-term finance as opposed to equity, while the interest cover ratio measures the cost of long term debt relative to earnings. In this sense, the interest cover ratio attempts to measure whether or not the company can afford the level of gearing that it has committed to.

${ }^{4}$ The financial accelerator occurs when a firm makes returns that are much higher than the required cashflows. This enables the firm to invest in positive net present value projects, which, in turn, further increases returns and profits. This process of increased financial resources continues or accelerates until the firm is unable to find any more positive NPV investments. See Bernanke et al. (1999) for a detailed discussion. 


\section{Figures and Tables}

Table 1: Shoprite: Highlights of Domestic and International Expansion, 1979 - 2008

\begin{tabular}{|c|c|}
\hline 1979 & $\begin{array}{l}\text { Establishment of the Shoprite Group of Companies with the purchase of a chain of } 8 \\
\text { Cape-based supermarkets from the Rogut family. }\end{array}$ \\
\hline 1983 & $\begin{array}{l}\text { Opens the first branch outside the Western Cape; and at the end of the year opens } 21 \mathrm{st} \\
\text { outlet in Worcester. }\end{array}$ \\
\hline 1984 & Purchases six food stores from Ackermans \\
\hline 1990 & Purchases the Grand Bazaars comprising of 27 stores \\
\hline 1991 & $\begin{array}{l}\text { Acquires the national Checkers chain of supermarkets, which for the first time gives the } \\
\text { Group country-wide representation. }\end{array}$ \\
\hline 1995 & $\begin{array}{l}\text { Opens the first store outside South Africa - Zambia; in the domestic market, acquires a } \\
\text { central buying organisation of } 550 \text { owner-manager supermarkets (Sentra) } *\end{array}$ \\
\hline 1997 & $\begin{array}{l}\text { Acquires ailing OK Bazaars Group (157 super and hyper sized supermar } \\
\text { stores); enters Quick Service Restaurant market through the Hungry Lion }\end{array}$ \\
\hline 2000 & $\begin{array}{l}\text { Enters a joint venture agreement with the Egypt-Kuwaiti Holding Company expecting to } \\
\text { open up investment opportunities in Egypt and the Middle East; and in the same year opens } \\
\text { stores in Uganda and Zimbabwe. }\end{array}$ \\
\hline 2001 & t in Malawi and Egypt $* *$ \\
\hline 2002 & $\begin{array}{l}\text { Acquires Score Supermarkets ( } 3 \text { supermarkets, a small distribution ce } \\
\text { acquires French-owned Champion supermarket group in Madagascar ( } 5 \\
\text { distribution centre); and opens first outlet in Mauritius. }\end{array}$ \\
\hline 2003 & Ghana (3 Usa \\
\hline 2004 & $\begin{array}{l}\text { Opens a wholesale operation in India and franchises its first Shoprite Hyper in Mumbai; } \\
\text { also opens a second supermarket in Uganda. }\end{array}$ \\
\hline 2005 & $\begin{array}{l}\text { Opens a store in Nigeria; acquires entire issued share capital of Computicket SA; launches } \\
\text { www.ticketshop.co.za to compliment its ticketing service by way of a dedicated web site; } \\
\text { purchases a chain of } 13 \text { retail supermarkets (Foodworld) \& } 4 \text { small wholesale outlets } \\
\text { (Saveworld) giving it presence in areas of the Western Cape where the brand is under- } \\
\text { represented. }\end{array}$ \\
\hline 2006 & nces the acceptance of a 13, 2 billion rand buyout. \\
\hline 2007 & $\begin{array}{l}\text { Plans to open } 91 \text { stores as part of } 545 \text { million rand capital investment programme in and } \\
\text { outside South Africa. }\end{array}$ \\
\hline 2008 & \\
\hline
\end{tabular}

Source: Company Reports (1999; 2000; 2001; 2002; 2003; 2004; 2005; 2006), African Business 2008

* The acquisition of Sentra substantially increased Shoprite's distribution capacity giving it the ability to enter into the franchising field and to compete in smaller markets where emphasis is on convenience.

** The Shoprite Group has since divested from Egypt citing a restrictive trading environment. 
Figure 1: Map of Shoprite Domestic and International Presence



Source: Adapted from the 2006 Shoprite Company Report and amended by authors. 
Table 2: Shoprite Business Units: Number, Location and Positioning, 2008

\begin{tabular}{|c|c|c|c|c|c|c|c|c|c|c|c|c|c|c|}
\hline & Shoprite & Checkers & $\begin{array}{l}\text { Checkers } \\
\text { Hyper }\end{array}$ & Usave & $\begin{array}{c}\text { OK } \\
\text { Furniture }\end{array}$ & OK Express & $\begin{array}{c}\text { House \& } \\
\text { Home }\end{array}$ & $\begin{array}{c}\text { Hungry } \\
\text { Lion }\end{array}$ & $\begin{array}{c}\text { OK } \\
\text { Foods }\end{array}$ & $\begin{array}{c}\text { OK } \\
\text { Grocer }\end{array}$ & $\begin{array}{c}\text { OK } \\
\text { Mini } \\
\text { Mark }\end{array}$ & $\begin{array}{c}\text { OK } \\
\text { Value }\end{array}$ & Mega-save & Sentra \\
\hline $\begin{array}{l}\text { Type of } \\
\text { business }\end{array}$ & $\begin{array}{l}\text { Food } \\
\text { super- } \\
\text { market }\end{array}$ & $\begin{array}{l}\text { Food super- } \\
\text { market }\end{array}$ & $\begin{array}{c}\text { Food and } \\
\text { GM } \\
\text { hypermarke } \\
\mathrm{t}\end{array}$ & $\begin{array}{c}\text { No-frills } \\
\text { discount } \\
\text { super- } \\
\text { market }\end{array}$ & $\begin{array}{l}\text { Furniture, \& } \\
\text { general } \\
\text { merchandise }\end{array}$ & $\begin{array}{c}\text { Smaller } \\
\text { metropolitan } \\
\text {-based } \\
\text { format of } \\
\text { OK } \\
\text { Furniture } \\
\end{array}$ & $\begin{array}{l}\text { Furniture, } \\
\text { and } \\
\text { electricals }\end{array}$ & $\begin{array}{l}\text { Fast food } \\
\text { restaurant }\end{array}$ & \multicolumn{4}{|c|}{ Franchised convenience stores } & $\begin{array}{c}\text { Franchised } \\
\text { wholesale/ca } \\
\text { sh \& carry }\end{array}$ & $\begin{array}{l}\text { Franchise } \\
\text { d super- } \\
\text { markets }\end{array}$ \\
\hline $\begin{array}{l}\text { Positioning } \\
\text { Index of } \\
\text { income (1- } \\
\text { lowest; } 10 \text { - } \\
\text { highest) }\end{array}$ & $\begin{array}{l}\text { Middle } \\
\text { income: } \\
4 \text { to } 7 .\end{array}$ & \multicolumn{2}{|c|}{$\begin{array}{l}\text { Higher end: } \\
7 \text { to } 10 .\end{array}$} & $\begin{array}{l}\text { Lower } \\
\text { income: } \\
1 \text { to } 5 .\end{array}$ & \multicolumn{2}{|c|}{$\begin{array}{c}\text { Middle/Higher income: } \\
5 \text { to } 8 .\end{array}$} & $\begin{array}{l}\text { Higher } \\
\text { income: } \\
7 \text { to } 10 .\end{array}$ & $\mathrm{n} / \mathrm{a}$ & \multicolumn{4}{|c|}{ Ranged for each community } & Wholesaler & $\begin{array}{c}\text { Mid- } \\
\text { market }\end{array}$ \\
\hline \multicolumn{15}{|l|}{ Country } \\
\hline South Africa & 302 & 116 & 24 & 86 & 161 & 13 & 33 & 93 & 16 & 51 & 28 & 12 & 36 & 61 \\
\hline Angola & 3 & & & 5 & & & & 1 & & & & & & \\
\hline Botswana & 4 & 1 & & & 4 & & & 3 & 5 & & & & 1 & \\
\hline Ghana & 1 & & & 1 & & & & & & & & & & \\
\hline India & 1 & & & & & & & & & & & & & \\
\hline Lesotho & 4 & & & 3 & 3 & 1 & & 2 & & 1 & & & & \\
\hline Madagascar & 6 & & & & & & & & & & & & & \\
\hline Malawi & 2 & & & 3 & & & & 2 & & & & & & \\
\hline Mauritius & 1 & & & & & & & & & & & & & \\
\hline Mozambique & 5 & & & & 2 & & & & & & & & & \\
\hline Namibia & 12 & 3 & & 10 & 10 & & 2 & 3 & 3 & 9 & 2 & 7 & 10 & 13 \\
\hline Nigeria & 1 & & & & & & & & & & & & & \\
\hline Swaziland & 6 & & & 2 & 1 & & & 1 & & & & & 1 & \\
\hline Tanzania & 5 & & & & & & & & & & & & & \\
\hline Uganda & 2 & & & & & & & & & & & & & \\
\hline Zambia & 16 & & & & & & & 7 & & & & & & \\
\hline Zimbabwe & 1 & & & & & & & & & & & & & \\
\hline Total & 372 & 120 & 24 & 110 & 182 & 14 & 35 & 112 & 24 & 61 & 30 & 19 & 48 & 74 \\
\hline
\end{tabular}

Source: from multiple sources within the Shoprite Annual Reports and

http://www.shoprite.co.za/default.asp?pageID=845664997 accessed at 11 June 2008 
Figure 2: Growth in Revenue and Net Profit at Shoprite: 1995 - 2006

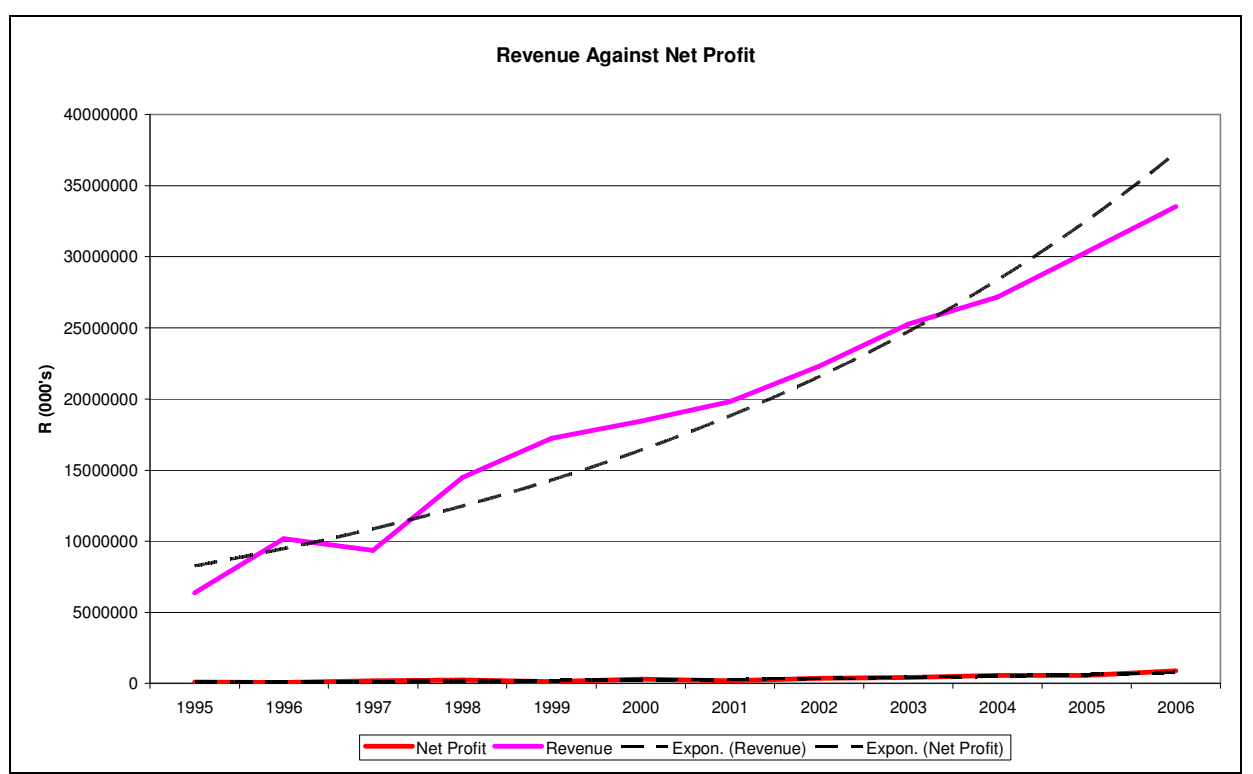

Source: Company Reports $(1999 ; 2000 ; 2001 ; 2002 ; 2003 ; 2004 ; 2005 ; 2006)$

Figure 3: Selected Financial Indicators

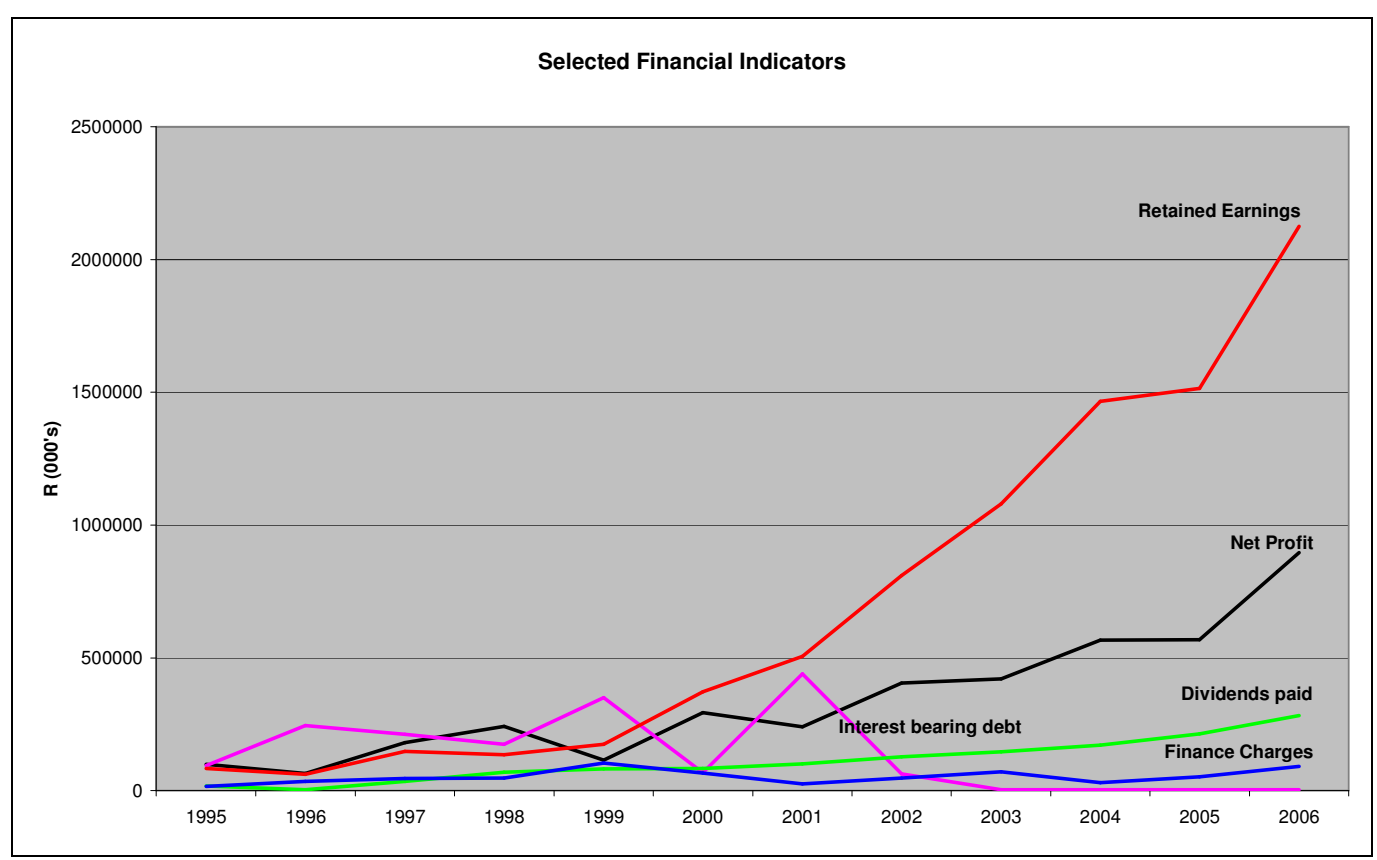


Source: Company Reports (1999; 2000; 2001; 2002; 2003; 2004; 2005; 2006)

Table 3: Key Financial Ratios of Shoprite Group

\begin{tabular}{|c|c|c|c|c|c|c|c|c|c|}
\hline & 1998 & 1999 & 2000 & 2001 & 2002 & 2003 & 2004 & 2005 & 2006 \\
\hline Debt:Equity & $16.0 \%$ & $31.0 \%$ & $39.8 \%$ & $34.8 \%$ & $4.3 \%$ & $0.1 \%$ & $0.1 \%$ & $0.1 \%$ & $0.1 \%$ \\
\hline Liabilities:Equity & 3.42 & 3.61 & 2.88 & 5.63 & 4.73 & 4.03 & 3.52 & 2.97 & n.d \\
\hline Current Ratio & 0.97 & 0.98 & 1.08 & 1.03 & 0.99 & 1.00 & 0.99 & 1.02 & 1.01 \\
\hline Quick Ratio & 0.39 & 0.45 & 0.48 & 0.56 & 0.49 & 0.47 & 0.52 & 0.52 & 0.48 \\
\hline Interest Cover & 5.08 & 1.23 & 5.00 & 4.32 & 6.47 & 6.56 & 21.10 & 19.22 & 16.99 \\
\hline Share Capital & 543479 & 543479 & 543479 & 543479 & 507761 & 507799 & 507387 & 507355 & 507345 \\
\hline Asset Turnover & 14.30 & 12.70 & 12.90 & 12.60 & 17.20 & 19.60 & 17.00 & 15.40 & n.d \\
\hline Stock Turnover & 9.70 & 8.30 & 8.80 & 8.30 & 9.10 & 9.30 & 8.20 & 8.50 & 8.90 \\
\hline $\begin{array}{l}\text { Operating } \\
\text { margin }\end{array}$ & $1.63 \%$ & $0.73 \%$ & $1.80 \%$ & $1.70 \%$ & $2.14 \%$ & $1.82 \%$ & $2.33 \%$ & $3.03 \%$ & $3.70 \%$ \\
\hline ROCE & $32.60 \%$ & $17.80 \%$ & $28.70 \%$ & $25.70 \%$ & $41.00 \%$ & $40.90 \%$ & $43.40 \%$ & $50.00 \%$ & n.d \\
\hline EPS & 45.70 & 21.00 & 54.10 & 32.30 & 73.70 & 81.40 & 111.70 & 111.90 & 175.40 \\
\hline Divs Per Share & 14.00 & 14.00 & 18.00 & 20.50 & 25.50 & 30.50 & 36.00 & 50.00 & 73.00 \\
\hline
\end{tabular}

Source: Company Reports (1999; 2000; 2001; 2002; 2003; 2004; 2005; 2006)

Figure 4: Issued Share Capital



Source: Company Reports (1999; 2000; 2001; 2002; 2003; 2004; 2005; 2006) 
Figure 5: Current Ratio Shoprite against Peers



Figure 6: Debt : Equity Ratio: Comparing Shoprite to Other Retailers

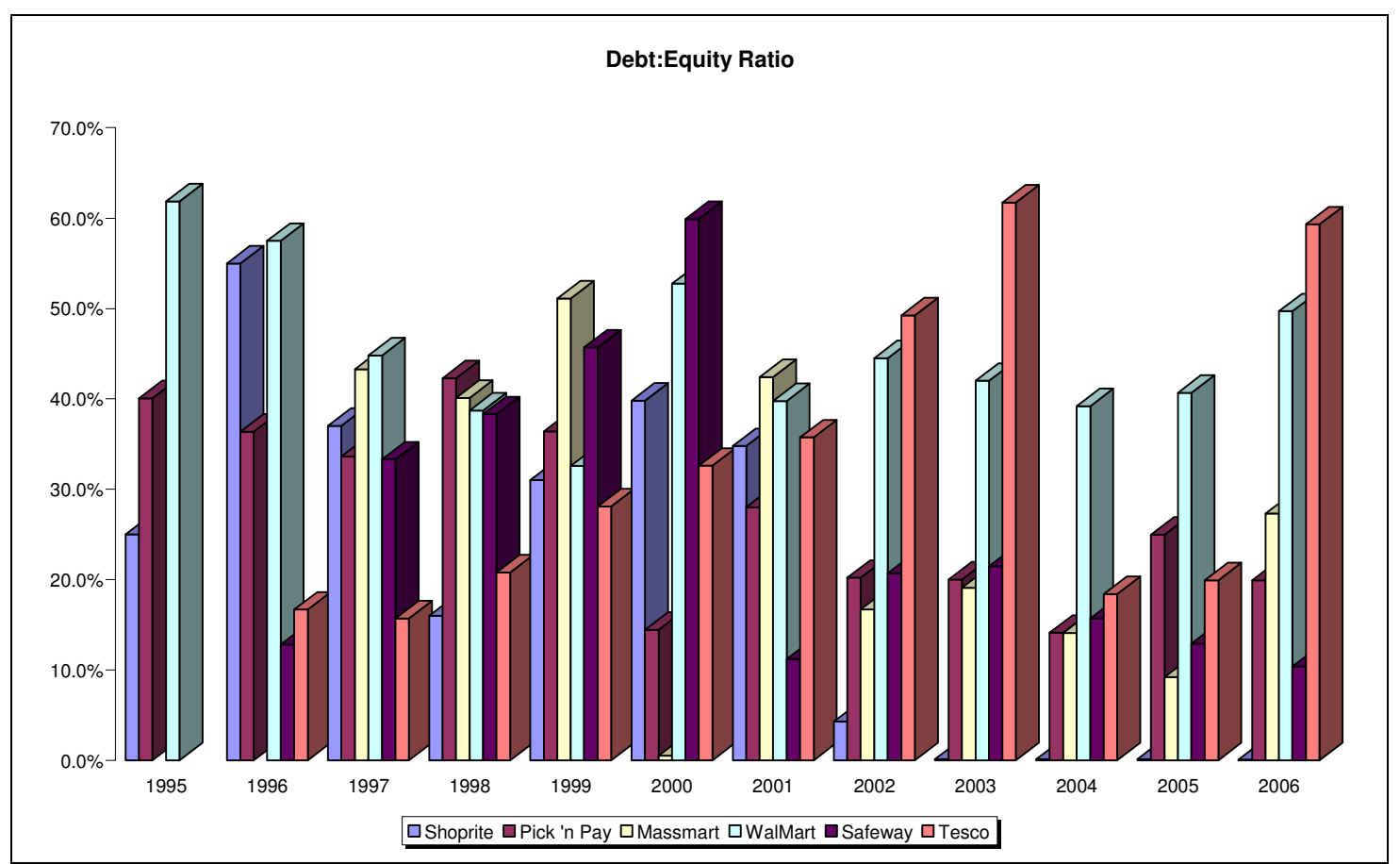


Acknowledgements: We wish to acknowledge the very able research assistance of JohnMark Mang'ana. We are grateful to Rohan Dyer of Bernard Jacobs Mellet, for useful information and arranging interviews. We also wish to thank both anonymous referees for their comments. Opinions expressed herein do not represent those of any of the above or the institutions which they work for, or are affiliated with. Errors, where they may still exist, are ours alone.

\section{References:}

African Business (2008) Shoprite targets DR Congo, African Business, February, Issue 339.

Aivazian, A., Ying, G., Qiu, J. (2005) The impact of leverage on firm investment:

Canadian evidence, Journal of Corporate Finance, 11: 277-291.

Alexander, N., Quinn, B. (2002) International retail divestment, International Marketing Review, 17: 334-353.

Antoniou, A., Guney, Y., Paudyal, K. (2008) The determinants of capital structure: capital market-oriented versus bank-oriented institutions, Journal of Financial and Quantitative Analysis, 43 (1): 59-92.

Aoyama, Y. (2007) Oligopoly and the structural paradox of retail TNCs: an assessment of Carrefour and Wal-Mart in Japan, Journal of Economic Geography, 7: 471-490.

Bauer, R., Braun, R. and Clark, G. (2008) The emerging market for European corporate governance: the relationship between governance and capital expenditures, 1997-2005, Journal of Economic Geography, 8(4): 441-469.

Bellalah, M., Belhaj, R. (2003) The effect of asymmetric information on the cost of capital. International Journal of Business, 8: 451-459.

Bernanke, B., Gertler, M., Gilchrist, S. (1999) The financial accelerator in a quantitative business cycle framework. In B Taylor, M Woodford (eds.), Handbook of Macroeconomics, Edition 1, Volume 1, Elsevier, Amsterdam: 1341-1393.

Bianchi, C., Ostale, E. (2006) Lessons learned from unsuccessful internationalization attempts: examples of multinational retailers in Chile, Journal of Business Research, 59, 140-147.

Burt, S. (2006) Royal Ahold: multinational, multi-channel, multi- format food provider. In J Dawson, R Larke and M Mukoyama (eds.) Strategic Issues in International Retailing, Routledge, London: 140-169.

Chowdhry, B., Coval, D. (1998) Internal financing of multinational subsidiaries: debt vs equity. Journal of Corporate Finance, 4: 87-106. 
Chowdhry, B., Nanda, V. (1994), Financing of multinational subsidiaries: Parent debt vs. external debt, Journal of Corporate Finance, 1: 259-281.

Christopherson, S. (2007) Barriers to US style lean retailing: the case of Wal-Mart's failure in Germany, Journal of Economic Geography, 7: 451-469.

Clark, G. (2008) Governing finance: global imperatives and the challenge of reconciling community representation with expertise, Economic Geography, 84: 281-302.

Clark, G., Hebb, T. (2005) Why should they care? The role of institutional investors in the market for corporate global responsibility, Environment and Planning A, 37: 2015-2031.

Clark, G., Salo, J., Hebb, T. (2008) Social and environmental shareholder activism in the public spotlight: US corporate annual meetings, campaign strategies and environmental performance, 2001-2004, Environment and Planning A, 40: 1370-1390.

Clark, G., Wójcik, D. (2005) Path dependence and financial markets: the economic geography of the German model, 1997 - 2003, Environment and Planning A, 37(10): 17691791

Clark, G. and Wójcik, D. (2007) The Geography of Finance: Corporate Governance in the Global Marketplace. Oxford University Press, Oxford.

Clark, G., Wojcik, D., Bauer, R. (2006) Geographically dispersed ownership and intermarket stock price arbitrage - Ahold's crisis of corporate governance and its implications for global standards, Journal of Economic Geography, 6: 303-322.

Clark, G., Wrigley N. (1997a) The spatial configuration of the firm and the management of sunk costs, Economic Geography, 73: 285-304

Clark, G., Wrigley N. (1997b) Exit, the firm and sunk costs: reconceptualizing the corporate geography of disinvestment and plant closure, Progress in Human Geography, 21: 338- 358.

Coe, N. (2006) The strategic localization of transnational retailers: the case of SamsungTesco in South Korea, Economic Geography, 82 (1): 61-88.

Coe, N., Hess, M. (2005) The internationalisation of retailing: implications for supply network restructuring in East Asia and Eastern Europe. Journal of Economic Geography, 5: 449-473.

Coe, N., Wrigley, N. (2007) Host economy impacts of transnational retail: the research agenda, Journal of Economic Geography, 7:341-371.

Coe, N., Wrigley, N. (2009) Introduction: profiling the emerging multi-disciplinary literature on the globalization of retailing and its impacts. In Coe, N. and Wrigley, N. The Globalization of Retailing, 2 Volumes, Edward Elgar, Cheltenham. 
Colla, E. (2003) International expansion of discount grocery retailers: the winning models, International Journal of Retail \& Distribution Management, 31: 55-66.

Dawson J (2007) Scoping and conceptualising retailer internationalisation, Journal of Economic Geography, 7: 373-397.

Doherty, A. (2007) The internationalization of retailing. Factors influencing the choice of franchising as a market entry strategy, International Journal of Service Industry Management, 18 (2): 181-205.

Donaldson, G. (1961) Corporate Debt Capacity: A Study Of Corporate Debt Policy and The Determination Of Corporate Debt Capacity. Boston: Harvard.

Dyson, A., Rasaratnam, S. (2006) UK retailers: what motivates the decision to raise finance? Journal of Retailing and Consumer Services, 13: 51-65.

Eldomiaty, T. (2007) Determinants of corporate capital structure: evidence from an emerging economy, International Journal of Commerce and Management, 17 (1/2): 25-43.

Fazzari, M., Hubbard, G., Petersen, C.B. (1988) Financing constraints and corporate investment, Brookings Papers on Economic Activity, 1: 141-206.

Gabrielson, M., Sasi, V., Darling, J. (2004) Finance strategies of rapidly-growing Finnish SMEs: born internationals and born globals, European Business Review, 16: 590-604.

Hebb.,T., Wójcik, D. (2005) 'Global standards and emerging markets: the institutionalinvestment value chain and the CalPERS investment strategy', Environment and Planning, A, 37(11): 1955-1974.

Heins, O. (2005), A Future for African Retailing, 12 July 2005. Accessed at Planet Retail: http://www.planetretail.net/Home/PressReleases/PressRelease.aspx?Archive=True\&PressRe leaseID $=34299$ on $29^{\text {th }}$ July 2008.

Hughes, A., Buttle, M., Wrigley, N. (2007) Organisational geographies of corporate responsibility: a UK-US comparison of retailers' ethical trading initiatives, Journal of Economic Geography, 7: 491-513.

Hughes, A., Wrigley, N., Buttle, M. (2008) Global production networks, ethical campaigning, and the embeddedness of responsible governance, Journal of Economic Geography, 8 (3): 345-367.

Humphrey, J. (2007) The supermarket revolution in developing countries: tidal wave or tough competitive struggle? Journal of Economic Geography, 7: 433-450.

Hutchinson R., Hunter R (1995) Determinants of capital structure in the retailing sector in the UK. International Review of Retail, Distribution \& Consumer Research, 5: 63-78. 
Jandik, T., Makhija, A. (2005) Debt, debt structure and corporate performance after unsuccessful takeovers: evidence from targets that remain independent, Journal of Corporate Finance, 11, 882-914.

Jensen, M., Meckling, W. (1976) Theory of the firm: managerial behavior, agency costs, and ownership structure, Journal of Financial Economics, 3 (4): 305-360.

Jonsson, A., Elg, U. (2006) Knowledge and knowledge sharing in retail internationalization: IKEA's entry into Russia, International Review of Retail, Distribution and Consumer Research, 16 (2): 239-256.

Kieso, E., Weygandt, J. (1986), Intermediate Accounting, Fifth Edition, John Wiley \& Sons, New Jersey.

Kochhar, R., Hitt, M. (1998) Research notes and communications linking corporate strategy, type and source of financing, Strategic Management Journal, 19: 601-610.

McCaffery, K., Hutchinson, R., Jackson, R. (1997) Aspects of the finance function: a review and survey into the UK retailing sector, International Review of Retail Distribution and Consumer Research, 7: 125-144.

Miller, D. (2005) New regional imaginaries in post-Apartheid southern Africa - retail workers at a shopping mall in Zambia, Journal of Southern African Studies, 31: 117 - 145.

Miller, D. (2006) Spaces of resistance- African workers at Shoprite in Maputo and Lusaka. Africa Development, 31: 27-49.

Moss, T., Ramachandran, V., Shah, M. (2005) Is Africa's skepticism of foreign capital justified? Evidence from East African firm survey data, In T. Moran, E. Graham and M. Blomström (eds.), Does Foreign Direct Investment Promote Development? Institute for International Economics, U.S: 337-366.

Myers, S. (1977) Interactions of corporate financing and investment decisions - implications for capital budgeting. Journal of Finance, 29: 1-25.

Myers, S., Majluf, S. N. (1984), Corporate financing and investment decisions when firms have information that investors do not have. Journal of Financial Economics, 13: 187-221.

Myers, S. (1984) The capital structure puzzle, Journal of Finance, 39 (3): 575-592.

Myers, S. (2001) Capital structure, Journal of Economic Perspectives, 15 (2): 81-102.

Okeahalam, C. (2005) Strategic alliances and mergers of financial exchanges: the case of the SADC, Journal of Southern African Studies, 31: 75-93.

Okeahalam C., Adams D. (2000) Banks and micro-finance in Namibia, South African Journal of Economics, 68: 118-150. 
O'Brien, J. (2003) The capital structure implications of pursuing a strategy of innovation, Strategic Management Journal, 24: 415-431.

Palmer, M. (2005) Retail multinational learning: a case study of Tesco. International Journal of Retail and Distribution Management, 33: 23-48.

Palmer, M. and O'Kane, P. (2007) Strategy as practice: interactive governance spaces and the corporate strategies of retail transnationals, Journal of Economic Geography, 7: 515-535.

Palmer, M. Owens, M., Sparks, L. (2006) Interdisciplinary (retail) research: the business of geography and the geography of business, Environment and Planning A, 38: 1514-1522.

Palmer, M., Quinn, B. (2003) The strategic role of investment banks in the retailer internationalisation process. Is the venture marketing? European Journal of Marketing, 37 (10): 1391-1408.

Palmer, M., Quinn, B. (2005) Stakeholder relationship in an international retailing context: an investment bank perspective, European Journal of Marketing, 39 (9/10): 1096-1117.

Palmer, M., Quinn, B. (2007) "The nature of international retail divestment: insights from Ahold”, International Marketing Review, 24 (1): 26-44.

Paul, S., Whittam, G., Wyper, J. (2007) The pecking order hypothesis: does it apply to startup firms? Journal of Small Business and Enterprise Development, 14: 8-21.

Reardon, T. (2005) Retail Companies as Integrators of Value Chains in Developing Countries: Diffusion, Procurement System Change, and Trade and Development Effects. Report commissioned by Federal Ministry for Economic Cooperation and Development, Germany. Accessed at http://www.regoverningmarkets.org/en/filemanager/active?fid=301 on 26 June 2008.

Reardon, T. Henson, S. Berdegue, J. (2007) Proactive fast tracking diffusion of supermarkets in developing countries: implications for market institutions and trade, Journal of Economic Geography, 7: 399-431.

Reardon, T., Neven, D. (2004) The rise of Kenyan supermarkets and the evolution of their horticulture product procurement systems, Development Policy Review, 22: 669-699.

Reardon, T., Timmer, C., Barrett, C., Berdegué, J. (2003) The rise supermarkets in Africa, Asia and Latin America, American Journal of Agricultural Economics, 85: 1140-1146.

Schleifer, A., Visny, R. (1997) A survey of corporate governance, Journal of Finance, 52: 737-783.

Shoprite (2008) Interim results analyst presentation for six months ended December 2007. Accessed at 
http://www.shoprite.co.za/files/19204235/Investor_Centre_Files/Interim\%202008/InterimFe b2008.pdf on 2nd July 2008.

Stonehill, A., Stitzel, T. (1969) Financial structure and multinational corporations. California Management Review, 12: 91-95.

Tokatli, N. (2007) Asymmetrical power relations and upgrading among suppliers of global clothing brands: Hugo Boss in Turkey, Journal of Economic Geography, 7: 67-92.

Tokatli, N. (2008) Global sourcing: insights from the global clothing industry - the case of Zara, a fast fashion retailer, Journal of Economic Geography, 8: 21-38.

Tustin, D., Strydom, J. (2006) The potential impact of formal retail chains' expansion strategies on retail township development in South Africa, Southern Africa Business Review, 10 (3): 48-66.

Weatherspoon D., Reardon T. (2003), The rise of supermarkets in Africa: implications for agrifood systems and the rural poor. Development Policy Review, 21: 333 - 355.

Whitley, R. (2001a) How and why are international firms different? The consequences of cross-border managerial coordination for firm characteristics and behaviour. In Morgan, G., Kristensen, P.H. and Whitley, R. (eds) The Multinational Firm: Organizing Across Institutional and National Divides, Oxford: Oxford University Press: 27-68.

Whitley, R. (2001b) The institutional structuring of business transactions. In Appelbaum, R., Felstiner, W. and Gessner, V. Rules and Networks: The Legal Culture of Global Business Transactions, Hart Publishing, Oxford: 73-102.

Wójcik, D. (2002) Cross-border corporate ownership and capital market integration in Europe: evidence from portfolio and industrial holdings. Journal of Economic Geography, 2(4): 455-491.

Wójcik, D. (2003) 'Change in the German model of corporate governance: evidence from blockholdings 1997 - 2001', Environment and Planning A, 35(8): 1431-1458.

Wójcik, D. (2006) 'Convergence in corporate governance: evidence from Europe and the challenge for economic geography', Journal of Economic Geography, 6(5): 639-660.

Wood, S. (2002) The limits to portfolio restructuring: lessons from regional consolidation in the US department store industry, Regional Studies, 36 (5): 515-529.

Wood, S. (2008) Reinterpreting the great US department store bankruptcies of the 1980s - a catalyst to strategic structural change, Journal of Management History, 14 (4): 404-423.

Wrigley, N. (1997) British food retail capital in the USA. Part 2: Giant prospects? International Journal of Retail and Distribution Management, 25 (2): 48-58. 
Wrigley, N. (1999a) Corporate finance, leveraged restructuring and the economic landscape: the LBO wave in US food retailing. In Martin, R.L (ed) Money and the Space Economy, John Wiley, Chichester: 185-205.

Wrigley, N. (1999b) Market rules and spatial outcomes: insights from the corporate restructuring of US food retailing, Geographical Analysis, 31: 288-309.

Wrigley, N. (2000b) Strategic market behaviour in the internationalization of food retailing: interpreting the third wave of Sainsbury's US diversification, European Journal of Marketing, 34: 891-918.

Wrigley, N., Coe, N., Currah, A. (2005) Globalizing retail: conceptualizing the distributionbased transnational corporation (TNC), Progress in Human Geography, 29 (4): 437-457.

Wrigley, N., Currah, A. (2003) The stresses of retail internationalization: lessons from Royal Ahold's experience in Latin America, International Review of Retail, Distribution and Consumer Research, 13: 221-243.

Wrigley, N., Lowe, M. (2007) Transnational retail and the global economy, Journal of Economic Geography, 7: 337-340. 